\section{Araştırma Makalesi (Research Article)}

Ege Üniv. Ziraat Fak. Derg.,2019, 56 (1):83-93

DOI: $10.20289 /$ zfdergi.438521

\title{
Farklı Yerel Bezelye (Pisum sativum L.) Hatlarının Bakteriyel Yanıklık Hastalığına Reaksiyonu
}

\author{
Pea Bacterial Blight Reactions of Several Pea (Pisum sativum L.) Lines
}

\author{
Alınış (Received): 06.06.2018 Kabul Tarihi (Accepted): 12.10 .2018
}

${ }^{1}$ Çukurova Üniversitesi Ziraat Fakültesi, Bitki Koruma Bölümü 01330 Adana

arcid : 0000-0002-3507-438X

'Orcid : 0000-0003-2647-5111

${ }^{2}$ Doğu Akdeniz Tarımsal Araştırma Enstitüsü, Kara-

taş Yolu Doğankent 01370 Adana

'Orcid : 0000-0002-2944-1227

${ }^{3}$ Erciyes Üniversitesi Ziraat Fakültesi, Bitki Koruma

Bölümü 38039 Kayseri

dOrcid : 0000-0002-5374-7082

sorumlu yazar: aysanys@cu.edu.tr

\section{Anahtar Sözcükler:}

Pseudomonas syringae pv. pisi, bezelye, duyarlılık, dayanıkııı, yerel hat

\section{Key Words:}

Pseudomonas syringae pv. pisi, pea, susceptibility, resistance, local line

\section{öz}

Amaç: Bu çalışmanın amacı; 29 farklı yerel bezelye hattının bakteriyel yanıklık hastalığına reaksiyonunun saksı ve Adana ilinde iki farklı lokasyonda kurulan tarla denemeleriyle belirlenmesidir.

Materyal ve Metot: Çalışmada, Doğu Akdeniz Tarımsal Araştırma Enstitüsü tarafından 19 farklı ilden toplanan 29 farklı yerel bezelye hattı ile iki çeşit (Jof ve Carina) kullanıımıştır. Üç farklı Pseudomonas syringae pv. pisi izolatından hazırlanan bakteriyel süspansiyon bezelye yapraklarına püskürtülerek hastalık düzeyi 0-5 skalası kullanılarak değerlendirilmiştir.

Bulgular: Yapılan çalışma sonucuna göre, dokuz yerel bezelye hattı ve kontrol olarak testlenen Carina çeşidi duyarlı, yerel hatlardan 18 tanesi ve diğer bir kontrol çeşidi Jof orta duyarlı, Konya yöresine ait üç bezelye hattı ise az duyarlı olarak bulunmuştur.

Sonuç: Pseudomonas syringae pv. pisi bezelyede bakteriyel yanıklık hastalığına neden olan patojen bir bakteridir. Hastalık, bezelye yetiştirilen pek çok ülkede görülen ve serin, yağışlı ve don olaylarının olduğu yerlerde duyarlı çeşitlerde yıkıcı zararlara neden olabilmektedir. Hastalıkla mücadelede dayanıklı çeşit seçimi ve sağlıklı tohum kullanımı ilk adım olmalıdır. Hastalıklara dayanıklı yerel çeşit geliştirme çalışmalarında Konya 153, Konya 154 ve Konya 155 isimli hatların ıslah çalışmalarına dahil edilmesinin uygun olacağı belirlenmiştir.

\section{ABSTRACT}

Objective: The aim of this study was to determine the bacterial pea blight reactions of 29 distinctive local pea lines with pot and both field experiments conducted in two individual locations of Adana county.

Material and Methods: Twenty nine different local pea lines that collected from 19 individual cities of Turkey by The Eastern Mediterranean Agricultural Research Institute and two disease susceptible pea varieties cv. Jof and cv. Carina tested in the present study. A suspension of three Pseudomonas syringae pv. pisi sprayed to pea leaves and disease severity was evaluated using the 0 to 5 scale.

Results: Nine local pea lines and cv. Carina were susceptible, 18 individual pea lines and cv. Jof were semi susceptible and three lines from Konya province were less susceptible to pea bacterial blight.

Conclusion: Pseudomonas syringae pv. pisi is the bacterium that causes bacterial pea blight. Disease is so severe and widespread in susceptible pea varieties that grown in warm, rainy and froze receiving countries. Pathogen-free seeds and disease resistant cultivars are the first step for disease control. This study suggested to include the three lines, Konya 153, Konya 154 and Konya 155 into the pea breeding programmes. 


\section{GíRiş}

Bezelye (Pisum sativum L.), kışlık veya yazlık olarak yetiştirilen, insan beslenmesinin dışında, hayvan yemi, ilaç sanayi, içki yapımı, karbonsuz kağıt üretiminde kullanılan bir bitkidir (Karayel ve Bozoğlu, 2012; Kavut ve Çelen, 2017). Ayrıca konserve ve dondurulmuş ürün olarak gıda sanayinin ham maddesidir.

Bezelye soğuk iklim koşullarını tolere edebilmesi, toprağın serbest azotunu fikse etmesi, toprak yapısını iyileştirmesi, yeşil gübre olarak kullanımı, üretim süresinin kısalığı nedeniyle günümüzde dünyanın birçok yerinde yetiştirilmektedir (Göre, 2003).

Dünya toplam kuru bezelye üretimi 11186123 tondur. Bu üretimin \%40'ı Amerika, \%21'i Asya ve \% 30'u Avrupa kıtalarında gerçekleştirilmektedir. Dünya toplam taze bezelye üretimi ise 17426421 ton olup Asya kıtası \% 86'lık pay ile en önemli üretici bölgedir (TÜiK, 2017). Türkiye kuru bezelye üretimi 2987 tondur. Bu üretimin büyük çoğunluğu İzmir, Konya ve Bursa illerinde gerçekleştirilmektedir. Türkiye taze bezelye üretimi 112643 tondur. Bursa taze bezelye üretiminde 38 bin ton ile ilk sırada yer alır. Afyon, Hatay, İzmir ve Balıkesir önemli taze bezelye üreticisi illerdir (TÜiK, 2017).

Pseudomonas syringae pv. pisi bezelyede bakteriyel yanıklık hastalığına neden olan bir bakteridir. Hastalık, bezelye yetiştirilen pek çok ülkede görülen ve uygun iklim koşullarında (serin, yağışıı ve don olaylarının olduğu yerler) duyarlı çeşitlerde yıkıcı zararlara neden olabilir (Fondevilla et al., 2012). Hastalığın belirtileri yapraklarda ve gövdede su emmiş lekelerin ardından küçük, zeytini yeşil rengindeki düzensiz lekelerin kahverengileşmesi ve ileri aşamada yaprakların incelerek kâğıt gibi olması şeklindedir. Meyve kapsüllerinde de benzer şekilde su emmiş lekeler gözlenir, daha sonra güneş yanığı renginde koyulaşır ve ileri dönemde koyu kahverengine dönüşür. Nemli koşullarda kapsüllerdeki lekelerin içinden bakteriyel akıntılar dışarıya sızar. Hollaway et al.(2007)'nin bildirdiğine göre bakteriyel yanıklık hastalığı ilk kez ABD'nin Colorado (1916) eyaletinde görülmüştür. Türkiye'de ise ilk kez 2007 yılında Adana'da Utrillo çeşidinde (Aysan, 2008), 2009 yılında Muğla, Aydın ve İzmir'in çeşitli ilçelerinde yetiştirilen Early Sweet, Geneva, Bolero ve Carina çeşitlerinde (Benlioğlu ve ark., 2010), 2014 yılında Adana'nın Yüreğir ilçesinde Carina ve Jof çeşitlerinde (Horuz ve ark., 2015) gözlenmiştir.

Etmen bezelye tohum kabuğunda yaşamını devam ettirir. Bulaşık tohumlar ekildiğinde fidelerdeki hastalık belirtileri uygun koşullarda 8-15 gün içinde ortaya çıkar. Bulaşık tohumların yetiştirilmesiyle bakteri toprağa bulaşır ve sulama suyuyla veya yağmurla tüm tarlaya yayılabilir. Patojenin tohumdaki toleransı sıfırdır. Bakla, yabani bezelye türleri, yabani fasulye türleri ve mercimek üzerinde etmen herhangi bir hastalık belirtisi oluşturmadan epifitik olarak bulunabildiği gibi bazen birkaç küçük lekeye de neden olabilir (Aysan, 2008).

Patojenin 7 farklı ırkı bilinirken son yıllarda Martin-Sanz et al., (2011) sekizinci ırkın varlığını ortaya koymuştur. Irk 2 özellikle ilkbaharda ekimi yapılan bezelyelerde yaygınken, ırk 4 ve 6 kışın ekimi yapılan bezelyelerde görülür. Tüm dünyada ırk 2 ve ırk 6 yaygınken ABD'de ırk 4'ün, Avustralya'da ırk 3'ün en yaygın ırk olduğu tespit edilmiştir (Hollaway et al., 2007). Ülkemizde hangi ırkların var olduğu bilinmemektedir.
Hastalığın 8 ırkına karşı dayanıklı olan bir bezelye çeşidi şimdiye kadar tespit edilmemiştir. Fakat ırk 2 ve 4'e dayanıklı çeşitler bulunmaktadır. Hastalığın mücadelesinde önerilecek herhangi bir kimyasal bulunmamaktadır. Bakırlı preparatların kullanılması hem ekonomik olmamakta, hem de üretim sezonunda yağış ve nem göz önüne alındığında bu uygulama yetersiz kalmaktadır. Özellikle don bölgelerinde kullanılacak tohumların kesinlikle hastalık yönünden incelenmiş olması gerekir. Hastalıklı bitki artıkları yok edilmeli ve bulaşık tarlalarda en az 3 yıl münavebe önerilmektedir. Alternatif konukçular da göz ardı edilmemelidir. Tek bir mücadele yöntemi yerine bunların tümü birlikte kullanıldığında hastalıkla mücadelede başarı sağlanabilir (Aysan, 2008; Martin-Sanz et al., 2011).

Bu çalışmada Doğu Akdeniz Tarımsal Araştırma Enstitüsü tarafından ülkemizin 19 farklı ilinden toplanan 29 farklı yerel bezelye hattının bakteriyel hastalığına duyarlılıkları araştııımıştır. Bu amaçla tarla denemeleri aynı anda iki farklı yerde Sarıçam ve Yüreğir ilçelerinde yürütülmüş, dayanıklı veya az duyarlı hatlar tespit edilerek ıslah çalışmalarına katkı sağlanmıştır.

\section{MATERYAL ve YÖNTEM}

\section{Patojen bakteri izolatları ve besi yerleri}

Horuz ve ark., (2015) tarafindan Pseudomonas syringae pv. pisi olarak tanılanan üç bakteri izolatı (AK 2r, AK 3r ve AK $5 r$ ) çalışmada kullanılmıştır. Çalışmada bakteri kültürlerinin çoğaltılmasında King B, izolatların buzdolabında saklanmasında ise Yeast Dextroz Kalsiyum Karbonat Agar (YDCA) besi yerleri kullanılmıştır (Lelliott and Stead, 1987).

\section{Bezelye Hatları}

Doğu Akdeniz Tarımsal Araştırma Enstitüsü'nde yürütülen Bezelye Islah Programında kullanılan, ülkemizin 19 farklı ilinden (Adana, Afyon, Antalya, Antakya, Balıkesir, Bingöl, Burdur, Bursa, Çanakkale, Çorum, Denizli, Gaziantep, Gümüşhane, İzmir, Kars, Konya, Manisa, Muğla, Tekirdağ) toplanan 29 farklı yerel bezelye hattı kullanılmıştır. Bu farklı hatlar, Doğu Akdeniz Tarımsal Araştırma Enstitüsü tarafından İzmir'in Menemen ilçesindeki Ege Tarımsal Araştırma Enstitüsü'nde bulunan Gen Bankasından ve ICARDA (International Center for Agricultural Research In The Dry Areas) popülasyonu olarak getirilmiş ve tek bir bitki seleksiyonu yapılarak saflaştırılmıştır. Kontrol olarak Jof ve Carina adlı çeşitler denemelere dahil edilmiştir.

\section{Farklı Bezelye Hatlarının Bakteriyel Yanıklık Hastalığına Reaksiyonu \\ Saksı denemesi}

Her bir bezelye hattına ait 20'şer adet tohum, her bir saksıya beşer adet olacak şekilde dört saksı toprağının iki cm derinliğine ekilmiştir. Her bir saksı bir tekrar kabul edilmiş ve çalışma dört tekrar, her tekrarda beş fide olacak şekilde deneme kurulmuştur. Saksılar açık alanda ortalama 22 ${ }^{\circ} \mathrm{C}$ 'de tutulmuştur. Bezelye tohumları yaklaşık 5-7 gün sonra çimlenmeye başlamış ve bitkiler $15-20 \mathrm{~cm}$ boya geldiğinde, üç Pseudomonas syringae pv. pisi izolatından hazırlanan $7 \times 10^{6}$ hücre/ml yoğunluğundaki süspansiyon, bezelye yapraklarına 
bir el pülverizatörü yardımıyla püskürtülmüştür (lqbal et al.,2013; Rodda et al., 2015).

Bitkilerin normal yetiştirme koşullarına göre bakımıyapılmış ve hastalık belirtileri gözlendikten sonra 15 gün arayla iki kez değerlendirme yapılmıştır. İlk değerlendirmede her bitkiden birer adet yaprak örneği alınarak 0-5 skalası (Şekil 1) kullanılarak değerlendirme yapılmıştır (Richardson and Hollaway, 2011; Martin-Sanz et al., 2012). İkinci değerlendirmede yaprak skorlamasında değişiklik olup olmadığı ve gövdede belirti oluşumu yönünden de inceleme yapılmıştır.

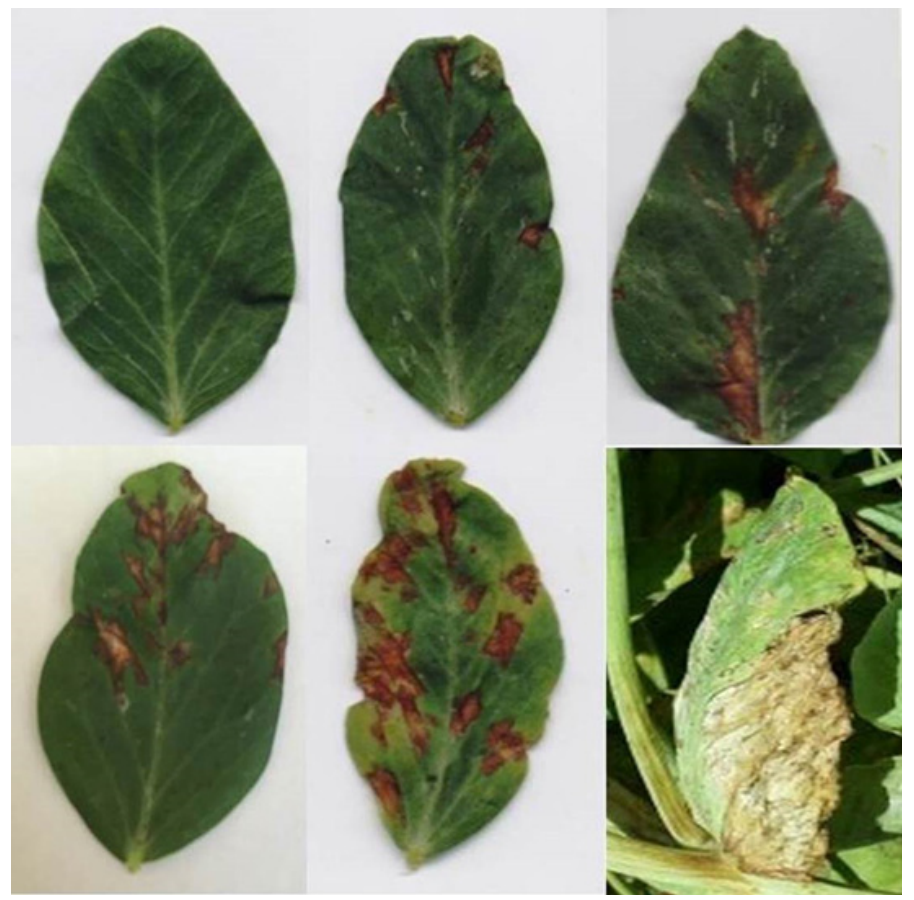

Şekil 1. Hastalık değerlendirmesinde kullanılan 0-5 skalası Figure 1. The scale 0 to 5 for evaluation of disease severity

\section{Tarla denemesi}

Farklı bezelye hatları 2014-2015 yetiştirme sezonunda Adana ilinin iki farklı lokasyonunda iki deneme kurulmuştur. Deneme alanının biri Sarıçam ilçesinde Ç. Ü. Ziraat Fakültesi Bitki Koruma Bölümü Araştırma ve Uygulama Parselinde $243 \mathrm{~m}^{2}$ lik alanda, diğeri Yüreğir ilçesinde Doğu Akdeniz Tarımsal Araştırma Enstitüsünde 243 m²lik alanda yetiştirilen bezelye bitkilerine patojen bakteri inokulasyonu ve ardından hatların bakteriyel yanıklık hastalığına duyarlılık düzeylerinin belirlenmesi şeklinde yürütülmüş̧ür.

Her bir bezelye hattına ait 35'er adet tohum dört tekrarlı (her bir alanda 140 adet tohum) olarak iki farklı deneme alanına (Sarıçam ve Yüreğir) 20 Kasım 2014 tarihinde sıra arası $45 \mathrm{~cm}$, sıra üzeri $6 \mathrm{~cm}$ olacak şekilde ekilmiştir. Bezelye bitkileri yaklaşık 25-30 cm boy ve çiçeklenme dönemine geldiğinde (Mart 2015) üç farklı Pseudomonas syringae pv. pisi izolatından hazırlanan $7 \times 10^{6}$ hücre/ml yoğunluğundaki süspansiyon, bezelye yapraklarına bir sırt pülverizatörü yardımıyla aynı gün püskürtülmüştür (lqbal et al., 2013). Bitkilerin normal yetiştirme koşullarına göre bakımı yapılmış ve hastalık belirtileri gözlendikten sonra yedi gün arayla üç kez değerlendirme yapılmıştır. Her bitkiden birer adet yaprak örneği alınarak (her hattın her tekrarından 35 yaprak olmak üzere, toplam 140 yaprak) 0-5 skalası (Şekil 1) kullanılarak değerlendirme yapılmıştır. Deneme boyunca her iki lokasyondaki günlük ortalama sıcaklık ve nem değerleri kayıt altına alınmıştır.

\section{Denemenin Değerlendirilmesi ve İstatistiki Analiz}

Elde edilen skala değerlerine göre hastalık indeksi hesaplanmış ve sonuçlar Tawsend-Heuberger formülünden faydalanılarak hastalık \%'sine dönüştürülmüştür. Hatlarda meydana gelen hastalık düzeyleri birbiriyle karşılaştırılarak ve aralarındaki istatistiki farklar hesaplanırken, hastalık \%'sinin açı değeri alınarak Duncan çoklu karşılaştırma testinde $\mathrm{p} \leq 0.05$ önem düzeyinde aynı istatistiki grupta yer alan uygulamalar aynı harfle işaretlenerek sonuçlar yorumlanmıştır.

$$
\begin{aligned}
& \text { Hastalık yüzdesi }=\frac{\operatorname{Toplam}(n \cdot V)}{Z \cdot N} \cdot 100 \\
& \mathrm{n}=\text { farklı skala değerine giren yaprak sayısı } \\
& \mathrm{V}=\text { skala değeri } \\
& \mathrm{Z}=\text { en yüksek skala değeri } \\
& \mathrm{N}=\text { değerlendirmeye alınan yaprak sayısı }
\end{aligned}
$$

\section{ARAŞTIRMA BULGULARI}

\section{Saksı denemesi}

Çizelge 1'de görüldüğü gibi yapılan değerlendirmede hiçbir bitkide 4 ve 5 skala değerinde hastalık görüntüsü ortaya çıkmamıştır. En fazla hastalık, ortalama 1.66 skala değeriyle TR-33372 Tekirdağ hattında \%33 oranında ortaya çıkmıştır. Bunu 1.58 skala değeriyle, \%31.66 hastalık oranıyla Balıkesir 133 ve İzmir 108 hatları izlemiştir. Bu üç bezelye hattı (TR33372 Tekirdağ, Balıkesir 133 ve İzmir 108) aynı istatistiki grupta yer almıştır. TR-37374 Çorum ve Manisa 159 hatları \%29.99 hastalık oranıyla ayrı bir grup oluşturmuştur. TR-33246 Çanakkale ve Afyon 150 hatları \%26.66 hastalık oranılla ayrı bir grup, TR-46469 Gümüşhane, TR-77737 Manisa (2) ve Bursa 18 hatları \%23.33 hastalık oranıla istatistiki olarak ayrı bir grupta değerlendirilmiştir. Yerel hatlardan 16 tanesi ve kontrol olarak kullanılan Carina ile Jof çeşitleri 1.0 skala değeri ve \%20 hastalık oranıyla ayrı büyük bir grubu oluşturmuştur. Konya yöresine ait üç yerel hat (Konya 153, Konya 154, Konya 155) en düşük skala değeri olan 0.5 skala değerinde yer almış, hastalık bu hatlarda \%10 oranında ortaya çıkmış ve ayrı bir grup oluşturmuştur.

Sonuç olarak saksı çalışmasında yedi yerel hat duyarlı, kontrol çeşitler (Carina ve Jof) dahil 21 yerel hat orta duyarlı ve Konya yöresine ait üç yerel hat ise az duyarlı olarak belirlenmiş ve istatistiki olarak da farklı grupta yer almışlardır. 
Çizelge 1. Farklı Bezelye Hatlarının Bakteriyel Yanıklık Hastalığına Reaksiyonu (Saksı Denemesi) Table 1. Disease reactions of several pea lines to pea bacterial blight (Pot experiment)

\begin{tabular}{|c|c|c|c|}
\hline Bezelye Hatları & Skala Ort. & Hastalık Oranı(\%) & Duyarlılık Düzeyi \\
\hline TR-33372 Tekirdağ & $1.66 \mathrm{a}^{*}$ & 33.33 & Duyarl1 \\
\hline Balıkesir 133 & $1.58 \mathrm{a}$ & 31.66 & Duyarlı \\
\hline İzmir 108 & $1.58 \mathrm{a}$ & 31.66 & Duyarlı \\
\hline TR-37374 Çorum & $1.50 \mathrm{ab}$ & 29.99 & Duyarlı \\
\hline Manisa 159 & $1.50 \mathrm{ab}$ & 29.99 & Duyarl1 \\
\hline TR-33246 Çanakkale & $1.33 \mathrm{abc}$ & 26.66 & Duyarlı \\
\hline Afyon 150 & $1.33 \mathrm{abc}$ & 26.66 & Duyarlı \\
\hline TR-46469 Gümüşhane & $1.17 \mathrm{bcd}$ & 23.33 & Orta Duyarlı \\
\hline TR-77737 Manisa (2) & $1.17 \mathrm{bcd}$ & 23.33 & Orta Duyarlı \\
\hline Bursa 18 & $1.17 \mathrm{bcd}$ & 23.33 & Orta Duyarlı \\
\hline TR-30760 Adana & $1.00 \mathrm{~cd}$ & 20.00 & Orta Duyarlı \\
\hline TR-77732 Muğla & $1.00 \mathrm{~cd}$ & 20.00 & Orta Duyarlı \\
\hline TR-77737 Manisa (1) & $1.00 \mathrm{~cd}$ & 20.00 & Orta Duyarl1 \\
\hline TR-80192 Burdur & $1.00 \mathrm{~cd}$ & 20.00 & Orta Duyarlı \\
\hline Afyon 146 & $1.00 \mathrm{~cd}$ & 20.00 & Orta Duyarlı \\
\hline Antalya 23 & $1.00 \mathrm{~cd}$ & 20.00 & Orta Duyarlı \\
\hline Antalya 80 & $1.00 \mathrm{~cd}$ & 20.00 & Orta Duyarlı \\
\hline Antalya 104 & $1.00 \mathrm{~cd}$ & 20.00 & Orta Duyarl1 \\
\hline Antakya 100 & $1.00 \mathrm{~cd}$ & 20.00 & Orta Duyarlı \\
\hline Bingöl 151 & $1.00 \mathrm{~cd}$ & 20.00 & Orta Duyarlı \\
\hline Bursa 20 & $1.00 \mathrm{~cd}$ & 20.00 & Orta Duyarlı \\
\hline Çanakkale 113 & $1.00 \mathrm{~cd}$ & 20.00 & Orta Duyarlı \\
\hline Denizli 8 & $1.00 \mathrm{~cd}$ & 20.00 & Orta Duyarlı \\
\hline G.Antep 94 & $1.00 \mathrm{~cd}$ & 20.00 & Orta Duyarlı \\
\hline Kars 49 & $1.00 \mathrm{~cd}$ & 20.00 & Orta Duyarlı \\
\hline Muğla 46 & $1.00 \mathrm{~cd}$ & 20.00 & Orta Duyarlı \\
\hline Jof & $1.00 \mathrm{~cd}$ & 20.00 & Orta Duyarlı \\
\hline Carina & $1.00 \mathrm{~cd}$ & 20.00 & Orta Duyarlı \\
\hline Konya 153 & $0.50 \mathrm{e}$ & 10.00 & Az Duyarlı \\
\hline Konya 154 & $0.50 \mathrm{e}$ & 10.00 & Az Duyarlı \\
\hline Konya 155 & $0.50 \mathrm{e}$ & 10.00 & Az Duyarlı \\
\hline
\end{tabular}

*Aynı harfle gösterilenler aynı istatistiki grupta yer alır ve Duncan çoklu karşılaştırma testi ( $\mathrm{p} \leq 0.05$ )'ne göre önemsizdir. 


\section{Tarla denemesi}

Tarla deneme sonuçları Çizelge 2'de verilmiştir. Bu sonuçlara göre; Sarıçam'da yapılan tarla denemesinde hastalık oranı, saksı ve Yüreğir'de yapılan tarla denemelerine göre daha yoğun olmuş ve 1-5 arasında skala değerinde ölçümler elde edilmiştir. En fazla hastalık \%48.28 oranı ve 2.41 skala değeriyle kontrol çeşidi Carina'da kaydedilmiş ve istatistiki olarak tek başına bir grup oluşturmuştur. Ardından, yerel hatlar içinde en fazla hastalık \%29.28 ile TR-30760 Adana hattında elde edilmiş ve ayrı bir grup içinde değerlendirilmiştir. Diğer kontrol çeşidi olan Jof ayrı bir istatistiki grupta yer almış ve hastalık \%24.42 oranında, 1.22 skala değerinde olmuştur. Yerel hatlardan 24'ünde hastalık \%20.00-23.13, skala değeri 1.0-1.16 arasında değişmekle birlikte tümü aynı istatistiki grupta yer almıştır. Saksı denemesine benzer şekilde en az hastalık Konya 155 hattında tespit edilmiştir. Konya 153 ve Konya 154 hatlarında tarlada hastalık gözlenmemiştir (Çizelge 2).

Kontrol çeşidi olan Carina, TR-30760 Adana ve Antakya 100 duyarlı, diğer kontrol çeşidi Jof ile yerel hatlardan 24 tanesi orta duyarlı, Konya 155 hattı az duyarlı, Konya 153 ve Konya 154 hatları ise hastalığa dayanıklı olarak değerlendirilmiştir (Çizelge 2).

Yüreğir'de kurulan diğer tarla denemesinde en yüksek hastalık \%25.85 oranı ve 1.32 skala değeriyle yine kontrol çeşidi olan Carina'da ortaya çıkmıştır. Bunu diğer kontrol

Çizelge 2. Farklı Bezelye Hatlarının Bakteriyel Yanıklık Hastalığına Reaksiyonu (Tarla Denemesi, Sarıçam) Table 2. Disease reactions of several pea lines to pea bacterial blight (Field experiment in Sarıçam)

\begin{tabular}{|c|c|c|c|}
\hline Bezelye Hatları & $\begin{array}{c}\text { Skala } \\
\text { Ort. }\end{array}$ & Hastalık Oranı(\%) & Duyarlılık Düzeyi \\
\hline Carina & $1.32 \mathrm{a}^{*}$ & 25.85 & Duyarlı \\
\hline Jof & $1.17 \mathrm{~b}$ & 23.42 & Orta Duyarlı \\
\hline Çanakkale 113 & $1.06 \mathrm{c}$ & 21.28 & Orta Duyarlı \\
\hline Denizli 8 & $1.03 \mathrm{c}$ & 20.57 & Orta Duyarlı \\
\hline Antakya 100 & $1.02 \mathrm{c}$ & 20.28 & Orta Duyarlı \\
\hline Bursa 20 & $1.01 \mathrm{c}$ & 20.14 & Orta Duyarlı \\
\hline TR-30760 Adana & $1.00 \mathrm{c}$ & 20.00 & Orta Duyarlı \\
\hline TR-33246 Çanakkale & $1.00 \mathrm{c}$ & 20.00 & Orta Duyarlı \\
\hline Balıkesir 133 & $1.00 \mathrm{c}$ & 20.00 & Orta Duyarlı \\
\hline Muğla 46 & $1.00 \mathrm{c}$ & 20.00 & Orta Duyarlı \\
\hline Bursa 18 & $1.00 \mathrm{c}$ & 20.00 & Orta Duyarlı \\
\hline Afyon 146 & $1.00 \mathrm{c}$ & 20.00 & Orta Duyarlı \\
\hline İzmir 108 & $1.00 \mathrm{c}$ & 20.00 & Orta Duyarlı \\
\hline TR-46469 Gümüşhane & $1.00 \mathrm{c}$ & 20.00 & Orta Duyarl1 \\
\hline TR-80192 Burdur & $1.00 \mathrm{c}$ & 20.00 & Orta Duyarlı \\
\hline TR-37374 Çorum & $1.00 \mathrm{c}$ & 20.00 & Orta Duyarlı \\
\hline TR-77737 Manisa (1) & $1.00 \mathrm{c}$ & 20.00 & Orta Duyarlı \\
\hline TR-77737 Manisa (2) & $1.00 \mathrm{c}$ & 20.00 & Orta Duyarlı \\
\hline TR-77732 Muğla & $1.00 \mathrm{c}$ & 20.00 & Orta Duyarlı \\
\hline TR-33372 Tekirdağ & $1.00 \mathrm{c}$ & 20.00 & Orta Duyarlı \\
\hline Afyon 150 & $1.00 \mathrm{c}$ & 20.00 & Orta Duyarlı \\
\hline Antalya 23 & $1.04 \mathrm{c}$ & 20.00 & Orta Duyarlı \\
\hline Antalya 80 & $1.00 \mathrm{c}$ & 20.00 & Orta Duyarlı \\
\hline Antalya 104 & $1.00 \mathrm{c}$ & 20.00 & Orta Duyarlı \\
\hline Bingöl 151 & $1.00 \mathrm{c}$ & 20.00 & Orta Duyarlı \\
\hline G.Antep 94 & $1.00 \mathrm{c}$ & 20.00 & Orta Duyarlı \\
\hline Kars 49 & $1.00 \mathrm{c}$ & 20.00 & Orta Duyarlı \\
\hline Manisa 159 & $1.00 \mathrm{c}$ & 20.00 & Orta Duyarlı \\
\hline Konya 155 & $0.00 \mathrm{~d}$ & 0.00 & Dayanıklı \\
\hline Konya 154 & $0.00 \mathrm{~d}$ & 0.00 & Dayanıklı \\
\hline Konya 153 & $0.00 \mathrm{~d}$ & 0.00 & Dayanıklı \\
\hline
\end{tabular}

*Aynı harfle gösterilenler aynı istatistiki grupta yer alır ve Duncan çoklu karşılaştırma testi (p $\leq 0.05$ )'ne göre önemsizdir. 
çeşidi olan Jof \%23.42 hastalık oranı ve 1.17 skala değeriyle izlemiştir. İstatistiki olarak incelendiğinde bu iki çeşit ayrı birer grup oluşturmuştur. Yerel hatlardan 26 tanesi \%20.00-21.28 arasındaki hastalık oranı ve 1.00-1.06 arasında skala değerinde yer alarak istatistiksel olarak büyük bir grup oluşturmuştur. Konya yöresine ait üç hatta hastalık gözlenmemiş̧ir (Çizelge 3). Bu sonuçlara göre Carina duyarlı, Jof ve 26 yerel bezelye hattı orta duyarlı, Konya yöresine ait üç yerel bezelye hattı Konya 153, Konya 154 ve Konya 155 ise dayanıklı olarak değerlendirilmiştir (Çizelge 3).

Sarıçam'da kurulan tarla denemesinde, bezelye bitkilerinde en yüksek hastalık oranı \%48.28 ile Carina çeşidinde tespit edilmiştir. Yüreğir'de kurulan tarla denemesinde, benzer şekilde en yüksek hastalık oranı yine Carina çeşidinde \%25.85 ile saptanmıştır (Çizelge 2 ve Çizelge 3). Ancak hastalık oranı Sarıçam'da kurulan denemede oldukça yüksekken, Yüreğir'de daha düşük olmuştur. Hastalık gelişiminin iklim ile olan ilişkisine bağlı olabileceği düşünülmüş ve iki farklı lokasyondaki iklim verileri karşılaştırılmıştır (Çizelge 4 ve 5). Sarıçam'da kurulan tarla denemesinin sıcaklık değerleri incelendiğinde, denemenin kurulduğu Kasım ayında ortalama en yüksek sıcaklık değeri $19^{\circ} \mathrm{C}$, ortalama nem değeri $\% 83$, patojen bakterinin bulaştırıldığı Mart ayında ortalama sıcaklık $17^{\circ} \mathrm{C}$, ortalama nem değeri \% 48-99 olurken, hasadın yapıldığı Mayıs ayında ortalama sıcaklık $21^{\circ} \mathrm{C}$ ve ortalama nem değeri \%81olmuştur (Çizelge 4).Yüreğir'de ise Kasım ayında ortalama sıcaklık $19^{\circ} \mathrm{C}$, ortalama nem değeri \%86, Mart ayında ortalama sıcaklık $19^{\circ} \mathrm{C}$, ortalama nem değeri $\% 44-88$ ve hasat zamanında ortalama sıcaklık $21^{\circ} \mathrm{C}$ ve ortalama nem değeri \%77 olarak ölçülmüştür (Çizelge 5).

\section{TARTIŞMA ve SONUÇ}

Doğu Akdeniz Tarımsal Araştırma Enstitüsü'nde yürütülen Bezelye Islah Programı kapsamında Türkiye'nin 19 farklı ilinden toplanan 29 farklı yerel bezelye hattının Pseudomonas syringae pv. pisi'nin neden olduğu bakteriyel yanıklık hastalığına reaksiyonunun saksı ve iki farklı lokasyondaki (Yüreğir ve Sarıçam) tarla denemeleriyle araştırıldığı bu çalışmada Konya yöresinden toplanan Konya 153, Konya 154 ve Konya 155 isimli hatlar hastalığa az duyarlı bulunmuştur. Pseudomonas syringae pv. pisi'nin neden olduğu bakteriyel yanıklık hastalığı serin, yağışı ve don olan iklim koşullarında duyarlı çeşitlerde yıkıcı zararlara neden olabilmektedir (Fondevilla et al., 2012). Bu nedenle hastalığın ülkemizde serin ve yağışlı bölgelerde çok büyük epidemi yapmasından dolayı tespit edilen az duyarlı bu üç bezelye hattının ülkemizde yaygınlaştırılması büyük önem taşımaktadır. Ayrıca bu hatlardan gerekli genler başka hatlara aktarılarak ıslahta bir materyal olarak kullanılabilir. Bu hastalıkla mücadelede dayanıklı çeşitlerin kullanımının önemi büyüktür. Pseudomonas syringae pv. pisi'nin farklı çeşitlerdeki reaksiyonu üzerine farklı ülkelerde pek çok çalışma (Hollaway et al., 2007; Martin-Sanz et al., 2011; Fondevilla et al., 2012; Martin-Sanz et al., 2012; lqbal et al., 2013; Rodda et al., 2015) yapılmasına karşın, ülkemizde böyle bir çalışma bulunmamaktadır. Dünyada şimdiye kadar patojenin tüm ırklarına dayanıklı bir çeşit tespit edilmemiş ve dolayısıyla piyasada bakteriyel yanıklık hastalığına dayanıklı ticari olarak satışı yapılan bezelye çeşitleri bulunmamaktadır.
Bu çalışmada saksılarda yürütülen denemelerde hastalık gelişimi yavaş olmuştur. Bunun nedeni olarak kullanılan saksıların büyüklüğünün yeterli olmadığı fikri oluşmuştur. Bezelye bitkileri hızla büyümüş, kullanılan saksıların büyüklüğü ve içerdiği toprak yeterli olmadığından, bitkilerin büyümesine olanak tanımamıştır. Bu nedenle bitkilerde büyüme durmuş ve hastalık daha fazla ilerleyememiştir. Bu sonuçlar dikkate alınarak hem sonuçların doğruluğunu görmek hem de farklı lokasyondaki hastalık gelişiminin benzerlik/farklılıklarını ortaya koymak amacıyla tarla denemeleri de yapılmıştır.

Tarla denemelerindeki sonuçlar değerlendirildiğinde iklimsel faktörlerin (nem, yağmurlu gün sayısı vb) farklı oluşu nedeniyle her iki tarlada aynı düzeyde hastalık ortaya çıkmamıştır. Her iki lokasyon karşılaştırıldığında patojen bakteri gelişimi için gerekli sıcaklık ve yüksek nem değerlerinin Sarıçam ilçesinde daha elverişli olduğu gözlenmiştir. Bakteriyel kökenli yaprak hastalıklarının şiddetli belirti oluşturması için yağış, nem ve bunlara bağlı olarak yaprak ıslaklık süresi son derece önemlidir. Patojen bakteri bezelye bitkilerine bulaştırıldıktan sonra Çizelge 4'te görüldüğü gibi yağışlı gün sayısı ve miktarı en fazla Sarıçam'da görülmüştür. Yüreğir'de deneme alanına yağışın az düşmesi ve bu alanda rüzgarın fazla olması sebebi ile yaprak ıslaklık süresi azalmış ve bunlara bağlı olarak hastalık belirtileri daha az görülmüştür. Benzer nedenlerle Martin-Sanz et al., (2012) kontrollü koşullarda yapılan denemelerin tarla çalışmalarına göre daha kabul edilebilir olduğunu belirtmektedir. Tüm bu bilgiler ışığında her üç deneme ortak olarak incelenmiş ve en fazla hastalık çıkışının olduğu durum değerlendirilmiştir.

Yapılan bu çalışmada Konya yöresinden toplanan Konya 153, Konya 154, Konya 155 kodlu hatlar hastalığa az duyarlı olarak belirlenmiştir. Doğu Akdeniz Tarımsal Araştırma Enstitüsü'nde yürütülen Bezelye Islah Programı kapsamında, Pseudomonas syringae pv. pisi'nin neden olduğu bezelyede bakteriyel yanıklık hastalığına dayanıklı çeşit geliştirme çalışmalarında Konya 153, Konya 154 ve Konya 155 isimli hatların ıslah çalışmalarına dahil edilmesi uygun olacaktır.

Bu hastalıkla mücadeledeki en önemli strateji dayanıklı çeşitlerin kullanımıdır. Martin-Sanz ve ark., (2012) yabani bezelye hatları dahil 242 bezelye hattını, yazlık ve kışlık ekimlerde, Pseudomonas syringae pv. pisi'nin 7 ırkı ile inokule etmişlerdir. Değerlendirme sonunda 44 bezelye hattı patojenin yedi ırkına duyarlı olarak tespit edilmiştir. Sonuç olarak patojenin yedi ırkına dayanıklı çeşit tespit edilememiştir. Benzer şekilde çalışmamızda hastalığa dayanıklı hat tespit edilmemiştir. Ancak yabani bezelye hatlarında dayanıklılık genlerinin varlığı belirlenmiş ve melezlemelerde bunlardan faydalanılabileceğinden söz edilmiştir. lqbal ve ark., (2013) 110 bezelye hattına Pseudomonas syringae pv. pisi'nin iki ırkını (ırk 2 ve 3) suni olarak bulaştırmış ve değerlendirme yapmıştır. Pseudomonas syringae pv. pisi'nin 2 nolu ırkına 30 hat dayanıklı, 31 hat duyarlı, 49 hat orta derecede duyarlıyken 3 nolu ırkına 18 hat dayanıklı, 64 hat duyarlı, 34 hat orta derecede duyarlı olarak saptanmıştır. Ülkemizde Pseudomonas syringae pv. pisi'nin hangi ırkı veya ırklarının var olduğu bilinmemektedir. Bunları belirleyecek bezelye çeşit koleksiyonuna sahip olmadığımız için bununla ilgili herhangi bir çalışma yapılamamıştır. Bu nedenle ülkemizden izole edilen virülensliği 
yüksek üç izolatın karışımı araştırmada kullanılmıştır (Horuz et. al. 2015). Sonuç olarak saksı ve iki farklı lokasyondaki tarla denemeleri değerlendirildiğinde, dokuz yerel hat (TR-30760 Adana, TR-33246 Çanakkale, TR-37374 Çorum,TR-33372 Tekirdağ, Afyon 150, Antakya 100, Balıkesir 133,Izmir 108, Manisa 159) ve kontrol olarak kullanılan Carina çeşidi duyarlı olarak değerlendirilmiştir (Çizelge 6). Yerel bezelye hatlarından 17 tanesi (TR-80192 Burdur, TR-46469 Gümüşhane, TR-77737 Manisa (1), TR-77737 Manisa (2), TR-77732 Muğla, Afyon 146, Antalya 23, Antalya 80, Antalya 104, Bingöl 151, Bursa 18, Bursa 20, Çanakkale 113, Denizli 8, Gaziantep 94, Kars 49, Muğla 46) ve kontrol olarak kullanılan Jof çeşidi orta duyarlı olarak değerlendirilmiştir. Konya yöresinden toplanan yerel üç bezelye hattı Konya 153, Konya 154, Konya 155 az duyarlı olarak değerlendirilmiştir.

Yapılan bu çalışmayla hastalığa az duyarlı olarak belirlenen üç bezelye hattının (Konya 153, Konya 154, Konya 155) veülkesel bezelye hatlarının patojenin farklı ırklarına reaksiyonunun gelecekte yapılacak çalışmalarla ortaya konması faydalı olacaktır. Ayrıca bu hatların diğer bir bakteriyel etmen
Pseudomonas syringae pv. syringae'ye, fungal hastalıklara (özellikle antraknoza) ve soğuğa olan reaksiyonunun da araştırılması gerekmektedir. Martin-Sanz ve ark., (2012) don olayına dayanıklı çeşitlerin bakteriyel yanıklık hastalığına da dayanıklı olduğundan bahsetmektedir. Pseudomonas syringae pv. pisi'nin ve Pseudomonas syringae pv. syringae'nin buz kristali oluşturma yeteneğine sahip izolatlarının don olayını teşvik ettiği bilinmektedir. Bezelyenin tarlada yetişme sezonunda $-6^{\circ} C^{\prime}$ de 7 gün dayanabildiği bildirilmiştir (Aysan, 2008) ancak Pseudomonas syringae'nin bakteriyel popülasyonu yaprak yüzeyinde belli bir popülasyona ulaştığında bitkiler $-2^{\circ} \mathrm{C}^{\prime} y e$ sadece 4 gün dayanabilmekte ve sonuçta bitkiler daha erken donmaktadır. Sonuç olarak gelecekte bezelye ıslah programında kullanılmak üzere bu çalışmada önemli veriler elde edilmiştir.

Çalışmada elde edilen bulgular T.C. Tarım ve Orman Bakanlığı'na bağlı Doğu Akdeniz Tarımsal Araştırma Enstitüsü'nde bezelye ıslah programında çalışan ıslahçı ve araştırıcılarla paylaşılmış ve çalışmalarda kullanılan bezelye hatlarının özelliklerine eklenmesi sağlanmıştır.

Çizelge 3. Farklı Bezelye Hatlarının Bakteriyel Yanıklık Hastalığına Reaksiyonu (Tarla Denemesi, Yüreğir) Table 3. Disease reactions of several pea lines to pea bacterial blight (Field experiment in Yüreğir)

\begin{tabular}{|c|c|c|c|}
\hline Bezelye Hatları & $\begin{array}{c}\text { Skala } \\
\text { Ort. }\end{array}$ & Hastalık Oranı(\%) & Duyarlılık Düzeyi \\
\hline Carina & $2.41 \mathrm{a}^{*}$ & 48.28 & Duyarlı \\
\hline TR-30760 Adana & $1.46 \mathrm{~b}$ & 29.28 & Duyarlı \\
\hline Antakya 100 & $1.36 \mathrm{bc}$ & 27.13 & Duyarlı \\
\hline Jof & $1.22 \mathrm{~cd}$ & 24.42 & Orta Duyarlı \\
\hline TR-33246 Çanakkale & $1.16 \mathrm{~d}$ & 23.13 & Orta Duyarlı \\
\hline Balıkesir 133 & $1.10 \mathrm{~d}$ & 21.28 & Orta Duyarlı \\
\hline Muğla 46 & $1.08 \mathrm{~d}$ & 21.57 & Orta Duyarlı \\
\hline Bursa 18 & $1.07 \mathrm{~d}$ & 21.42 & Orta Duyarlı \\
\hline Bursa 20 & $1.07 \mathrm{~d}$ & 21.42 & Orta Duyarlı \\
\hline Afyon 146 & $1.06 \mathrm{~d}$ & 21.28 & Orta Duyarlı \\
\hline İzmir 108 & $1.05 \mathrm{~d}$ & 20.99 & Orta Duyarlı \\
\hline Denizli 8 & $1.04 \mathrm{~d}$ & 20.71 & Orta Duyarlı \\
\hline TR-46469 Gümüşhane & $1.02 \mathrm{~d}$ & 20.28 & Orta Duyarlı \\
\hline TR-80192 Burdur & $1.00 \mathrm{~d}$ & 20.00 & Orta Duyarlı \\
\hline TR-37374 Çorum & $1.00 \mathrm{~d}$ & 20.00 & Orta Duyarlı \\
\hline TR-77737 Manisa (1) & $1.00 \mathrm{~d}$ & 20.00 & Orta Duyarlı \\
\hline TR-77737 Manisa (2) & $1.00 \mathrm{~d}$ & 20.00 & Orta Duyarlı \\
\hline TR-77732 Muğla & $1.00 \mathrm{~d}$ & 20.00 & Orta Duyarlı \\
\hline TR-33372 Tekirdağ & $1.00 \mathrm{~d}$ & 20.00 & Orta Duyarlı \\
\hline Afyon 150 & $1.00 \mathrm{~d}$ & 20.00 & Orta Duyarlı \\
\hline Antalya 23 & $1.00 \mathrm{~d}$ & 20.00 & Orta Duyarlı \\
\hline Antalya 80 & $1.00 \mathrm{~d}$ & 20.00 & Orta Duyarlı \\
\hline Antalya 104 & $1.00 \mathrm{~d}$ & 20.00 & Orta Duyarlı \\
\hline Bingöl 151 & $1.00 \mathrm{~d}$ & 20.00 & Orta Duyarlı \\
\hline Çanakkale 113 & $1.00 \mathrm{~d}$ & 20.00 & Orta Duyarlı \\
\hline G.Antep 94 & $1.00 \mathrm{~d}$ & 20.00 & Orta Duyarlı \\
\hline Kars 49 & $1.00 \mathrm{~d}$ & 20.00 & Orta Duyarlı \\
\hline Manisa 159 & $1.00 \mathrm{~d}$ & 20.00 & Orta Duyarlı \\
\hline Konya 155 & $0.05 \mathrm{e}$ & 1.00 & Az Duyarlı \\
\hline Konya 154 & $0.00 \mathrm{f}$ & 0.00 & Dayanıklı \\
\hline Konya 153 & $0.00 \mathrm{f}$ & 0.00 & Dayanıklı \\
\hline
\end{tabular}


Çizelge 4. Sarıçam İlçesindeki Tarla Denemesi Sıcaklık Değerleri $\left({ }^{\circ} \mathrm{C}\right)$ Table 4. Temperature rates of field experiment in Sarıçam County

\begin{tabular}{|c|c|c|c|c|c|c|c|}
\hline & Kasım & Aralık & Ocak & Şubat & Mart & Nisan & Mayıs \\
\hline 1 & \begin{tabular}{|l|}
16.00 \\
\end{tabular} & 12.82 & 10.81 & 11.62 & 13.26 & 15.16 & 18.64 \\
\hline 2 & 15.00 & 13.33 & 9.90 & 11.78 & 13.73 & 14.36 & 19.36 \\
\hline 3 & 14.00 & 15.40 & 8.86 & 9.63 & 12.90 & 14.83 & 17.67 \\
\hline 4 & 12.00 & 14.90 & 8.31 & 10.93 & 12.85 & 14.61 & 19.28 \\
\hline 5 & 12.00 & 14.33 & 8.95 & 11.59 & 11.01 & 13.84 & 20.17 \\
\hline 6 & 13.00 & 14.55 & 10.38 & 12.69 & 11.29 & 14.95 & 20.32 \\
\hline 7 & 14.41 & 16.46 & 6.32 & 13.28 & 15.04 & 15.61 & 21.45 \\
\hline 8 & 15.79 & 17.45 & 2.74 & 12.43 & 16.29 & 16.74 & 21.68 \\
\hline 9 & 18.01 & \begin{tabular}{|l|}
13.60 \\
\end{tabular} & 2.08 & 12.77 & 16.38 & 16.90 & 20.15 \\
\hline 10 & 16.38 & 12.75 & 1.21 & 9.49 & \begin{tabular}{|l|l}
17.78 \\
\end{tabular} & 11.86 & 21.13 \\
\hline 11 & 15.84 & \begin{tabular}{|l|}
14.37 \\
\end{tabular} & 5.18 & 7.44 & 13.70 & 11.86 & 19.04 \\
\hline 12 & \begin{tabular}{|l|}
16.47 \\
\end{tabular} & 15.27 & 5.96 & 8.63 & 11.02 & 13.49 & 20.44 \\
\hline 13 & 16.60 & 13.21 & 7.90 & 8.02 & 11.98 & 11.91 & 17.54 \\
\hline 14 & 19.06 & 12.07 & 9.64 & 9.43 & 13.53 & 13.06 & 17.90 \\
\hline 15 & 17.89 & 10.95 & 7.00 & 10.37 & 10.54 & 15.36 & 19.57 \\
\hline 16 & \begin{tabular}{|l|}
16.89 \\
\end{tabular} & \begin{tabular}{|l|}
10.37 \\
\end{tabular} & 7.38 & 9.82 & 11.50 & 17.17 & 20.66 \\
\hline 17 & 15.50 & 11.17 & 8.31 & 9.03 & \begin{tabular}{|l}
11.99 \\
\end{tabular} & 16.04 & 22.83 \\
\hline 18 & 15.03 & 12.55 & 7.22 & 7.12 & 12.90 & 16.76 & 26.03 \\
\hline 19 & 15.18 & 1.35 & 7.77 & 5.30 & 12.36 & 15.54 & 27.74 \\
\hline 20 & 16.73 & 1.41 & 8.34 & 7.47 & 10.33 & 17.08 & 25.38 \\
\hline 21 & 13.15 & 1.11 & 9.44 & 8.29 & 9.00 & 16.18 & 22.57 \\
\hline 22 & 12.62 & 9.99 & 9.81 & 7.59 & 10.58 & 14.41 & 21.06 \\
\hline 23 & 13.25 & 7.70 & 10.78 & 9.93 & 10.83 & 11.71 & 21.88 \\
\hline 24 & 13.18 & 8.33 & 13.84 & 12.28 & \begin{tabular}{|l|l}
13.27 \\
\end{tabular} & 12.39 & 22.73 \\
\hline 25 & 11.49 & 9.60 & 14.94 & 10.11 & 13.84 & 14.24 & 22.92 \\
\hline 26 & 9.39 & 11.55 & 10.46 & 11.50 & 14.40 & 16.85 & 21.60 \\
\hline 27 & 9.58 & 12.43 & 10.29 & 14.16 & \begin{tabular}{|l|l|}
17.83 \\
\end{tabular} & 18.81 & 22.10 \\
\hline 28 & 10.32 & 11.35 & 8.18 & 16.07 & 16.54 & 20.96 & 22.48 \\
\hline 29 & 10.80 & 12.48 & 10.02 & & 16.43 & 19.66 & 21.11 \\
\hline 30 & 11.66 & 12.86 & 9.13 & & 14.70 & 18.00 & 27.17 \\
\hline 31 & & 11.85 & 9.75 & & 15.48 & & 20.55 \\
\hline $\begin{array}{l}\text { Ortalama } \\
\left({ }^{\circ} \mathrm{C}\right)\end{array}$ & 14.33 & 12.53 & 8.42 & 10.31 & 13.33 & 15.34 & 21.39 \\
\hline
\end{tabular}


Çizelge 5. Yüreğir ilçesindeki Tarla Denemesi Sıcaklık Değerleri $\left({ }^{\circ} \mathrm{C}\right)$ Table 5. Temperature rates of field experiment in Yüreğir County

\begin{tabular}{|c|c|c|c|c|c|c|c|}
\hline & Kasım & Aralık & Ocak & Şubat & Mart & Nisan & Mayıs \\
\hline 1 & 17.00 & 14.00 & 11.00 & 13.00 & 14.00 & 16.00 & 18.00 \\
\hline 2 & 16.00 & 13.00 & 11.00 & 14.00 & 14.00 & 14.00 & 21.00 \\
\hline 3 & 14.00 & 17.00 & 10.00 & 12.00 & 13.00 & 16.00 & 18.00 \\
\hline 4 & 13.00 & 17.00 & 8.00 & 12.00 & 13.00 & 16.00 & 20.00 \\
\hline 5 & 13.00 & 16.00 & 9.00 & 13.00 & 12.00 & 14.00 & 21.00 \\
\hline 6 & 14.00 & 14.00 & 10.00 & 13.00 & 12.00 & 16.00 & 21.00 \\
\hline 7 & 16.00 & 17.00 & 7.00 & 14.00 & 16.00 & 17.00 & 21.00 \\
\hline 8 & 17.00 & 18.00 & 3.00 & 12.00 & 18.00 & 17.00 & 22.00 \\
\hline 9 & 18.00 & 14.00 & 2.00 & 13.00 & 18.00 & 16.00 & 21.00 \\
\hline 10 & 19.00 & 13.00 & 1.00 & 10.00 & 19.00 & 11.00 & 21.00 \\
\hline 11 & 17.00 & 14.00 & 6.00 & 8.00 & 14.00 & 11.00 & 21.00 \\
\hline 12 & 17.00 & 15.00 & 4.00 & 9.00 & 11.00 & 13.00 & 21.00 \\
\hline 13 & 17.00 & 13.00 & 8.00 & 9.00 & 13.00 & 12.00 & 19.00 \\
\hline 14 & 19.00 & 13.00 & 10.00 & 9.00 & 14.00 & 13.00 & 19.00 \\
\hline 15 & 18.00 & 12.00 & 9.00 & 11.00 & 12.00 & 16.00 & 20.00 \\
\hline 16 & 17.00 & 12.00 & 8.00 & 10.00 & 12.00 & 18.00 & 21.00 \\
\hline 17 & 17.00 & 12.00 & 9.00 & 10.00 & 13.00 & 16.00 & 24.00 \\
\hline 18 & 17.00 & 13.00 & 8.00 & 8.00 & 13.00 & 17.00 & 27.00 \\
\hline 19 & 16.00 & 13.00 & 9.00 & 6.00 & 14.00 & 16.00 & 29.00 \\
\hline 20 & 17.00 & 13.00 & \begin{tabular}{|l|}
10.00 \\
\end{tabular} & 8.00 & 11.00 & 18.00 & 28.00 \\
\hline 21 & 12.00 & 11.00 & 11.00 & 8.00 & 11.00 & 17.00 & 23.00 \\
\hline 22 & 12.00 & 9.00 & 11.00 & 7.00 & 10.00 & 15.00 & 21.00 \\
\hline 23 & 13.00 & 8.00 & 12.00 & 10.00 & 10.00 & 13.00 & 21.00 \\
\hline 24 & 13.00 & 9.00 & 14.00 & 12.00 & 14.00 & 13.00 & 22.00 \\
\hline 25 & 12.00 & 10.00 & 16.00 & 11.00 & 14.00 & 14.00 & 23.00 \\
\hline 26 & 9.00 & 12.00 & 12.00 & 12.00 & 14.00 & 18.00 & 22.00 \\
\hline 27 & 10.00 & 13.00 & 12.00 & 14.00 & $\mid 17.00$ & 19.00 & 22.00 \\
\hline 28 & 11.00 & 11.00 & 9.00 & 17.00 & 16.00 & 22.00 & 23.00 \\
\hline 29 & 11.00 & 13.00 & 11.00 & & 17.00 & 22.00 & 22.00 \\
\hline 30 & 11.00 & 13.00 & 8.00 & & 16.00 & 17.00 & 18.00 \\
\hline 31 & & 12.00 & \begin{tabular}{|l|l}
10.00 \\
\end{tabular} & & $\mid 17.00$ & & 20.00 \\
\hline $\begin{array}{l}\text { Ortala } \\
\text { ma } \\
\left({ }^{\circ} \mathrm{C}\right)\end{array}$ & 14.70 & 13.00 & 8. 90 & 10.90 & 13.90 & 15.80 & 21.70 \\
\hline
\end{tabular}


Çizelge 6. Farklı Bezelye Hatlarının Bakteriyel Yanıklık Hastalığına Duyarlılık Düzeyi

Table 6. Disease reactions of several pea lines to pea bacterial blight

\begin{tabular}{|c|c|c|c|c|}
\hline \multirow[b]{2}{*}{ Bezelye Hatları } & \multicolumn{4}{|c|}{ Duyarlılık Düzeyi } \\
\hline & Saksı Denemesi & $\begin{array}{c}\text { Tarla } \\
\text { (Yüreğir) }\end{array}$ & $\begin{array}{c}\text { Tarla } \\
\text { (Sarıçam) }\end{array}$ & Genel \\
\hline TR-30760 Adana & Orta Duyarlı & Orta Duyarlı & Duyarl1 & Duyarlı \\
\hline TR-33246 Çanakkale & Duyarlı & Orta Duyarlı & Orta Duyarlı & Duyarlı \\
\hline TR-37374 Çorum & Duyarlı & Orta Duyarlı & Orta Duyarlı & Duyarlı \\
\hline TR-33372 Tekirdağ & Duyarlı & Orta Duyarlı & Orta Duyarlı & Duyarlı \\
\hline Afyon 150 & Duyarlı & Orta Duyarlı & Orta Duyarlı & Duyarlı \\
\hline Antakya 100 & Orta Duyarlı & Orta Duyarlı & Duyarlı & Duyarlı \\
\hline Balıkesir 133 & Duyarlı & Orta Duyarlı & Orta Duyarlı & Duyarlı \\
\hline İzmir 108 & Duyarlı & Orta Duyarlı & Orta Duyarlı & Duyarlı \\
\hline Carina & Orta Duyarlı & Duyarlı & Duyarlı & Duyarlı \\
\hline Manisa 159 & Duyarlı & Orta Duyarlı & Orta Duyarlı & Duyarlı \\
\hline Jof & Orta Duyarlı & Orta Duyarlı & Orta Duyarlı & Orta Duyarlı \\
\hline TR-80192 Burdur & Orta Duyarlı & Orta Duyarlı & Orta Duyarlı & Orta Duyarlı \\
\hline TR-46469 Gümüșhane & Orta Duyarlı & Orta Duyarlı & Orta Duyarlı & Orta Duyarlı \\
\hline TR-77737 Manisa (1) & Orta Duyarlı & Orta Duyarlı & Orta Duyarlı & Orta Duyarlı \\
\hline TR-77737 Manisa (2) & Orta Duyarlı & Orta Duyarlı & Orta Duyarlı & Orta Duyarlı \\
\hline TR-77732 Muğla & Orta Duyarlı & Orta Duyarlı & Orta Duyarlı & Orta Duyarlı \\
\hline Afyon 146 & Orta Duyarlı & Orta Duyarlı & Orta Duyarlı & Orta Duyarlı \\
\hline Antalya 23 & Orta Duyarlı & Orta Duyarlı & Orta Duyarlı & Orta Duyarlı \\
\hline Antalya 80 & Orta Duyarlı & Orta Duyarlı & Orta Duyarlı & Orta Duyarlı \\
\hline Antalya 104 & Orta Duyarlı & Orta Duyarlı & Orta Duyarl1 & Orta Duyarlı \\
\hline Bingöl 151 & Orta Duyarlı & Orta Duyarlı & Orta Duyarlı & Orta Duyarlı \\
\hline Bursa 18 & Orta Duyarlı & Orta Duyarlı & Orta Duyarlı & Orta Duyarlı \\
\hline Bursa 20 & Orta Duyarlı & Orta Duyarlı & Orta Duyarlı & Orta Duyarlı \\
\hline Çanakkale 113 & Orta Duyarlı & Orta Duyarlı & Orta Duyarlı & Orta Duyarlı \\
\hline Denizli 8 & Orta Duyarlı & Orta Duyarlı & Orta Duyarlı & Orta Duyarlı \\
\hline G.Antep 94 & Orta Duyarlı & Orta Duyarlı & Orta Duyarlı & Orta Duyarlı \\
\hline Kars 49 & Orta Duyarlı & Orta Duyarlı & Orta Duyarlı & Orta Duyarlı \\
\hline Muğla 46 & Orta Duyarlı & Orta Duyarlı & Orta Duyarlı & Orta Duyarlı \\
\hline Konya 153 & Az Duyarlı & Dayanıklı & Dayanıklı & Az Duyarlı \\
\hline Konya 154 & Az Duyarlı & Dayanıklı & Dayanıklı & Az Duyarlı \\
\hline Konya 155 & Az Duyarlı & Dayanıklı & Az Duyarlı & Az Duyarlı \\
\hline
\end{tabular}




\section{KAYNAKLAR}

Aysan, Y. 2008. Bezelyede bakteriyel yanıklık hastalığı. In: Bitki Bakteri Hastalıkları (Eds: H. Saygıl1, F. Şahin ve Y. Aysan), İzmir, s. 109-111.

Benlioğlu, K., Ü. Özyılmaz ve D. Ertan, 2010. First report bacterial blight caused by Pseudomonas syringae pv. pisi on pea in Turkey. Plant Disease 94(7)923.

Fondevilla, S.,A. Marti'n-Sanz, Z. Satovic, M.D.F. Romero, D. Rubiales and C.Caminero, 2012. Identification of quantitative trait loci involved in resistance to Pseudomonas syringae pv. syringae in pea (PisumsativumL.). Euphytica 186:805-812.

Göre, E. 2003. Bezelye'de Ascochyta Hastalıklarıyla Biyolojik Mücadelede Fluoresent Pseudomonas'ların Etkisinin Saptanması Üzerinde Araştırmalar. Ege Üniversitesi, Fen Bilimleri Enstitüsü, Bitki Koruma Anabilim Dalı Doktora Tezi Sayfa 172.

Hollaway, G.J., T.W. Bretagand T.V. Price, 2007.The epidemiology and management of bacterial blight (Pseudomonas syringae pv. pisi) of field pea (Pisum sativum) in Australia: a review. Australian Journal of Agricultural Research, 58:1086-1099.

Horuz, S., A. Koksal-Akca, M. Guneş, B.P. Aktepe and Y. Aysan, 2015. Occurence of bacterial blight caused by Pseudomonas syringae pv. pisi in the Eastern Mediterranean Region of Turkey. XVIII International Plant Protection Congress; Berlin, Almanya, pp. 741.

Iqbal, S.M.,A. Javaid, A. Bakhshand S.R. Malik, 2013. Molecular characterization of pea for resistance to Pseudomonas syringae pv. pisi. International Journal of Agriculture and Biology, 15(4)787-790.

Karayel, R. ve H. Bozoğlu, 2012. Samsun'da ekilen bezelye genotiplerinin bazı fizikokimyasal özelliklerinin belirlenmesi ve 1slah materyali olarak uygunluğunun değerlendirilmesi. Ondokuz Mayıs Üniversitesi, Fen Bilimleri Enstitüsü, Tarla Bitkileri Anabilim Dalı Doktora Tezi Sayfa 162.

Kavut Y.T. ve A.E Çelen, 2017. Kimi yembezelyesi çeşitlerinde (Pisum arvense L.) sıra arası mesafelerinin tohum verimi ile bazı verim özelliklerine etkisi üzerinde bir araştırma. Ege Üniv. Ziraat Fak. Dergisi 54 (1):79-83.

Lelliott, R.A. and D.E. Stead,1987. Methods for the Diagnosis of Bacterial Diseases of Plants. 2. Basım. Blackwell Scientific Publications. Oxford. UK. 219 pp.

Marti'n-Sanz, A., J.L. Palomo, De L.V.M. Pe'rez and C. Caminero, 2011. Identification of pathovars and races of Pseudomonas syringae, the main causal agent of bacterial disease in pea in North-Central Spain, and the search for disease resistance. European Journal of Plant Pathology 129:57-69.

Marti'n-Sanz, A., De L.V.M. Pe'rez and C. Caminero, 2012. Resistance to Pseudomonas syringae in a collection of pea germplasm under field and controlled conditions. PlantPathology 61:375-387.

Richardson, H.J. and G.J. Hollaway, 2011. Bacterial blight caused by Pseudomonas syringae pv. syringae shown to be an important disease of field pea in southeastern. Australasian Plant Pathology, 40:260-268.

Rodda, M.S., P. Kant, K.D. Lindbeck, A. Gnanasambandam and G.J. Hollaway, 2015. A high-throughput glasshouse based screening method to evaluate bacterial blightresistance in field pea (Pisum sativum). Australasian Plant Pathol 44:515-526.

TÜIK, 2017. Türkiye İstatistik Kurumu. https://biruni.tuik.gov.tr/ bitkiselapp/bitkisel.zul. Erişim Haziran 2018. 